\title{
Malaysian Siam Music in Northern Malaysia and Its Representation
}

\section{Chayuti Tassanawongwara}

\begin{abstract}
Some of the Thais were left behind in some parts of the land which once a Thailand's territory. In the colonialism era, after Kelantan, Terangganu, Perlis and Kedah were annexed to Malaysia several decades ago by British, the Malaysian Siam who have chosen to stay put became the citizens of Malaysia despite being defined as Thais. The livelihood conditions of different nationalities are vital tools to distinguish one ethnic race from others. The first Malaysian Siam who ventured their way from South Thailand to settle in the land known as Melayu can be traced as far back as 300-500 years ago during the reign of King Boromma Trailokanat of Ayudhya era. There was an evidence of migration from then North Thailand downwards to the land of Melayu and inhabited at Sai Buri town. Today, the Malaysian Siams are densely populated across Kelantan, Perak, Perlis and Kedah. In this regard, it is a hard decision to choose the appropriate tools to represent the cultural identity. Music, in all possibilities, could be a likely solution to representation of cultural identity by importing them from its land of origin to reflect the unity of Thai people and the Malaysian Siam. Once the music is allowed to make its impact in protecting the identity of the Thai. This paper shall redound to the representation of Malaysian Siam in northern Malaysia, locally states of Perlis and Kedah, especially music in current use. The paper shall thoroughly present the result of analysis how the Malaysian Siam uses music to strengthen their cultural identity by the process of representation through a focusing on the theory of liminality.
\end{abstract}

Keywords: representation, malaysian siam, klong yao

\section{INTRODUCTION}

This study is intended to contribute the field of cultural identity representation. It is based on previous studies and theories. The consistency of this research emphasizes to explain a cultural identity through music dimension and its process. The study is focused on diverse theories including identity theory, liminality theory, and representation. 
The concept of culture is a notoriously difficult one. As Raymond Williams commented 'Culture is one of the two or three most complicated words in the English language'. However, it is inescapable in discussion of nationalism. Of its many senses, three are especially important here.

In one significant sense, a culture consists of gallery of meaningful or representative objects which those with the appropriate cultural knowledge and identity can interpret and evaluate. In this sense, culture exists as a public realm. However-and this is the second sense-the concept of culture also refer to the way in which these object are crated, recreated and modified. In this sense, culture is process rather than product. A culture is not made once and for all. It is continually being remade, reaffirmed and something changed. Cultural objects may change their meaning or become less central; new objects may be introduced. Even the most static culture is the scene contestation, reinterpretation and criticism, and reproduced. In a third sense, the concept of culture refers to the process by which people acquire the knowledge which allows them to understand the various cultural artifacts and to recognize them as their own. It is the process by which members of the culture come to understand the meaning of the object which form the culture and, crucially, find their identity in these objects. In this final sense, culture is education or information. It is the process by which an individual is inscribed within a particular form of life (Poole, 1999: 11-12).

According to Richard A. Rogers, school of Communication, Northern Arizona University. I identified four categories of cultural appropriation. Based on the assumptions identified, these four categories can best be understood as naming the conditions (historical, social, political, cultural, and economic) under which acts of appropriation occur.

1. Cultural exchange: the reciprocal exchange of symbols, artifacts, rituals, genres, and/or technologies between cultures with roughly equal levels of power.

2. Cultural dominance: the use of elements of a dominant culture by members of subordinated culture in a context in which the dominant culture has been imposed on the subordinated culture, including appropriation that enact resistance.

3. Cultural exploitation: the appropriation of elements of a subordinated culture by a dominant culture without substantive reciprocity, permission, and/or compensation.

4. Transculturation: cultural elements created from and/or by multiple cultures, such that identification of a single originating culture is problematic, for example, multiple cultural appropriations structured in the dynamics of globalization and transnational capitalism creating hybrid forms (Rogers, 2006: 477). 
What is it about national identity which has rendered these claims and sacrifices so terribly plausible? The beginnings of an answer to this question were provided by one of the very first theorists of nationalism, Johann Gottlieb Herder. Herder argued that a nation is constituted through its language and culture. He emphasized the significance of the practices, customs, and rituals of everyday life, and of the stories, folk beliefs and myths in term of which people make sense of their lives - indeed, he can claim to be the one of the first theorists of what we now call 'popular culture'. The most fundamental constituent of a culture was the language in which these stories, beliefs and myths find expression. Language and culture were not, Herder argued, merely aspects of the social environment within which people made their lives; they were constitutive of their very identity (Poole, 1999: 61).

According to Martin Stokes. As Ethnomusicologists have recently come to insist, it is important that music and dance in these kind of rituals are not just seen as static symbolic objects which have to be understood in a context, but are themselves a patterned context within which other things happen. What is important is not just musical performance, but good performance, if music and dance are to make a social event 'happen'. Complex aesthetic vocabularies, or single term covering a complex semantic terrain point to minute and shifting subtleties of rhythm and texture which make or break the event. Music is socially meaningful not entirely but largely because it provides means by which people recognize identities and places means by which separate them.

Ethnicity is perhaps the more problematic word. Ethnicity is 'an arguable and murky intellectual term' but one which nonetheless continues to be useful for a variety of reasons. Barth's seminal essay (1969) introduced the term in his analysis of boundary construction and maintenance. Ethnicities are to be understood in terms of construction' maintenance and negotiation of boundaries, and not on the putative social 'essence' which fill the gabs within them. Ethnic boundaries define and maintain social identities, which can only exist in 'a context of opposition and relativities'. The term ethnicity thus points to the central anthropological concern with classification (Martin Stokes, 1997: 5-6).

One of the important questions raised in the postmodernist 'texture turn' in anthropology is the question of anthropological representation of 'The Other'. In the process, traditional anthropological ethnographic 'texts' have been put under critical purview and interrogated. Forms of orientalist representations of 'The Other', the legacy of colonial anthropology and other forms of colonial knowledge, postmodernist ethnographic narratives and representations - all these have become critical themes of the discourse (Zawawi Ibrahim, 2008: 2). 


\section{Research Methodologies}

For this study, the process of Malaysian Siam cultural identity through music is mutually merged and interpreted with case studies of music (particularly Klong Yao) to conceptualize, represent, identify, and promote Malaysian Siam identity.

Qualitative research is about finding out not just what people think but why they think it. It's about getting people to talk about their opinions so you can understand their motivations and feelings. Moreover, Qualitative research is also to get people to expand on their answers so that you can get more insight into their attitudes and behavior. It is all about getting underneath people's responses to find out what is driving their decisions. The study wants to research the problem in the real life of Malaysian Siam and their status inside the community to explain the phenomenon of representation by using music through ceremonial events. The research not only emphasizes to finding research sources from descriptive research or library research but also further research an observation, participant observation, and interview.

Here of, primary and secondary data shall be collected from the following:

Primary Data and Secondary Data

- Library Research

The study considers in text books, articles, and archives, etc. Shall be entirely searched to combine in this study. The researcher reviews historical and theoretical book from libraries namely Thai national library, Prince of Songkla university library, Thaksin University library, and University of Malaya library. In addition, reading published such as materials, magazines, newspaper, journals are included as well as browsing websites and relevant dissertations.

- Observation

Several visitations of surveys and observations in the state of Perlis and Kedah particularly in Malaysian Siam community for finding materials and making familiarity and experience with the community identity. Survey and observation help the researcher to directly communicate and cooperate with the community as the visitor. The significant of observation is to reach into the community and music display respectfully and friendly.

- Participant Observation

The researcher has to attend in the ceremonies, rituals, religious observances, and traditional activities which accompanied by music throughout the process of 
dissertation writing. In this regard, the researcher needs to observe in the central places of the community such as local museum and Buddhist monastery.

The researcher is supposed to be accompanied by local guide to communicate profoundly with the community. Moreover, the researcher needs to spend a lot of field works of the study area for getting the data and expectation. A participant observation is the one of the most essential methods to assist the researcher achieve the result practically.

- Interviews

Interview is an important role for this study. The researcher interviews local people who have experienced in music display. The reference people will be classified into four groups including villagers and inhabitants, musicians and performers, leader of community, and abbots and monks. The interview mostly concentrates on Malaysian Siam music and cultural identity.

\section{Aim and Objective of the study}

The aim of the study is to study the role of Malaysian Siam music in Northern Malaysia in the process of representation and cultural identity through music.

Objectives of the study as follows:

1. To study background of Malaysian Siam society in Northern Malaysia and cultural identity representation.

2. To study the concept of Malaysian Siam identity, liminality, and representation.

3. To analyze Malaysian Siam music in Northern Malaysia and its Representation.

\section{Significance of the study}

The findings of this study shall redound to the representation of Malaysian Siam in northern Malaysia, locally states of Perlis and Kedah, especially music in current use. The study thoroughly presents the result of analysis how the Malaysian Siam uses music to strengthen their cultural identity by the process of representation through a focusing on the theory of liminality. For the research result, the music plays role to assist the community to identify themselves as Siam people albeit they are ethnic minority in the amidst of many other ethnic groups. Thus this dissertation is about to be initial research for Ethnomusicology of Malaysian Siam music in Northern Malaysia.

\section{Klong Yao: a representation of cultural identity}

The Tai is an ethnic race whose ancestry is studied, researched and analyzed upon various hypothesis regarding its ethnic origin. It is known that the Tais have not only settled 
its habitat in Thailand, but expanded over South East Asia and nearby areas. The dispersion of Tai ethnic race has seen them inhabiting in South China, Laos, Myanmar, some parts of India and North Malaysia.

The definition of the Tais and its differentiation from other ethnic races are based on number of indicating criteria, i.e. language, accent, religion, ritual, local tradition, etc. The language of Tai ethnic race is the Tai language, belonging to the Tai-Kadai language family. Evidently, each of different spoken languages of Tai ethnic race possess particular intonation while sharing common etymology and linguistic character. Religiously, the Tai ethnic race receives considerable influence of Buddhism although some of them may worship ancestors, spirits and sacred entities, resulting in number of rituals that the Tai ethnic race practice as a response to their religious and sacred creed.

The purpose of settling in may not be the only factor which is responsible for dislocation and scattering of some Tai ethnic group. Earlier, there was no distinct indicators of land separation. Later when borderlines came into effect to form a legitimate political map of various countries, the scattered Thais then united with the citizen within their respective countries. But the unique identity of the Thais had allowed them to assemble to form a small community that upholds their symbolic identity such as the Thai-Ahom in Assam state of India.

Some of the Tais were left behind in some parts of the land which once a Thailand's territory. In the post-colonialism era, after Kelantan, Perak, Perlis and Kedah were annexed to Malaysia several decades ago, the Malaysian Siam who have chosen to stay put became the citizens of Malaysia despite being defined as Thais. The livelihood conditions of different nationalities are vital tools to distinguish one ethnic race from others. Malaysian consists of people of numerous descents such as, Malay, Chinese, Indian and Thai. Being aboriginal dwellers of today's Malaysia territory, the Malay, above all other ethnic races, exclusively own the superior rights to claim the privilege of Bumiputera status. Also, that the Siam have different conditions, i.e. nationality, religion, language and customs; has even further emphasized the need of conservation of identity that separates them from the Bumiputera Malay citizens (Pakawal Bundirek, 2010: 7-8).

The first Malaysian Siam who ventured their way from South Thailand to settle in the land known as Melayu can be traced as far back as 300-500 years ago during the reign of King Boromma Trailokanat of Ayutthaya era. There was an evidence of migration from then North Thailand downwards to the land of Melayu and inhabited at Sai Buri town. Today, the Malaysian Siam are densely populated across Kelantan, Perak, Perlis and Kedah most of them earning their living through agricultures. Linguistically, these Malaysian Siam normally converse using the language of Nakhon Si Thammarat accent of Songkhla accent 
with similar intonation, vocabularies, grammar and other characteristics to that of Thai language. Thai language is also taught to young Malaysian Siam for daily basis and for the language's sake itself based on the Bangkok's system of academic regulations. Regarding the condition of the Malaysian Siam, they are recognized by the Malaysia's official registration to hold Thai ethnic race and Malay nationality. Although some of these Malaysian Siam converted to Muslim, majority of them are dedicated Buddhists (Tassanavadee Keawsanit, 2015: 3-4) who regularly practice important rituals in different occasions such as Magha Puja, Asalha Puja, Visakha Puja, Buddhist Sabbhath. The Buddhist core value of ordination is still being observed by the Malaysian Siam so strongly that some family are even willing to send their child at due age all the way to Thailand only for ordination. Apart from this, other Buddhism-associated rituals and the traditions of the Central Thailand are highly appreciated.

The traditions that reflect Thainess has been continuously inherited and passed on while some are transferred and reproduced according to Thailand's current mainstream traditions such as Songkran and Loikrathong, both of them playing a vital part in current Malaysian Siam's lifestyle. It is clear that these traditions emulate that of Thailand and flourish elsewhere. Also, it is equally obvious that arts and music also inevitably share major contribution in the cultural activities since both connect and harmonize the traditions of cheerful Thai and the Malaysian Siam. Li-GE BANTON and NANG TALUNG (Vajeeyaporn Chatavaraha, 2010: 6). Are few exemplary results of such cultural exchange and influence between two races. Stories narrated during these performances are portrayed in the light of religious and customary perspectives of the locals. The songs are sung as a medium of storytelling, symbolizing an archive of the history surrounded with balanced aesthetics and at the same time keeping the Thai ethnic identity thriving through various processes, some of them are in the form of arts and music.

Not only there is an exchange of culture and tradition between Thai people of the South and the Malaysian Siam, but also cultural importation as an apparent reinforcement of cultural strength. Loykrathong tradition is undoubtedly a great example of cultural importation because the tradition did not exist originally in any part of Malaysian Siam area. Regarding music, there is no denial that it plays an important part of cultural activities. (Surasak Jumnongsarn, 2014: Interview). Importing the music based on its popularity in Thailand is another attempt to reproduce Thailand's musical semblance. This kind of duplication is interpreted to construct cultural identity through musical dimension. From time to time, LOOG THONG music, along with dancers and full complete band, have added a touch of extravagance to Songkran and Loikratong tradition. KLONG YAO ensemble, which take part in such auspicious ceremonies as ordination, 
represents an entertaining yet simple identity of Central Thailand and the Malaysian Siam are able to seamlessly fit these music tradition into their cultural activities very well.

Besides serving entertainment to mankind, using music for constructing identity is another interesting issue, particularly when music is given an interpretation as means for constructing cultural identity of the Malaysian Siam. Choosing KLONG YAO ensemble shall, by the above accounts, be a favorable case study. Moreover, KLONG YAO ensemble has never been granted rights to engage in Malaysian Siam customs until recently that it becomes very vital to Malaysian Siam's way of life to the extent that developed into a defining identity of Thai culture.

Since the Thai ethnic race in Melayu territory are surrounded with vast diversity of languages, religions and culture, they have an increasing likelihood to be the victim of creolization and may have to surrender to autocracy under some sorts of governmental system which may utilize unfamiliar measures to Malaysian Siam. So government policies and entitlement are crucial parameters that can possibly break down the identity of a minority known as Thai. On the contrary, an undeterred willingness to preserve identity of Thai under stressed situation plus the selection of rather mild resorts for presenting cultural identity exhibits Thai's peaceful and cordial nature. In this regard, it is a hard decision to choose the appropriate tools to reproduce the cultural identity. Music, in all possibilities, could be a likely solution to reproduction of cultural identity by importing them from its land of origin to reflect the unity of Thai people and the Malaysian Siam. Once the music is allowed to make its impact in protecting the identity of the Thai, it could, to the benefits of Malaysian Siam, be a very intriguing subject for study and research.

\section{CONCLUSION}

The study wants to describe an analysis of representation of Malaysian Siam people who unavoidably make cultural identity for defending their community and enrich a Siamese among situations of ambiguous status and government policy. The Malaysian Siam music is not only used for entertainment but also efficiently presents the prominent point of cultural identity and be understood through accompaniment in traditional events. The researcher desires to gather Malaysian Siam music in many occasions and events.

Relationship between a researcher and local people whether Buddhist or Muslim may contribute to a progression of this study. Nevertheless, this study shall be seemingly an initial research based on ethnomusicology and combination of histories and anthropological, social, and music theories which explain the phenomena of representation on Malaysian Siam music. Some situations can be interpreted by liminality theory. This study is in the process of research and field work. 




Figure 1. Klong Yao band and a procession of orditaion (Photo: Chayuti Tassanawongwara, 2015)

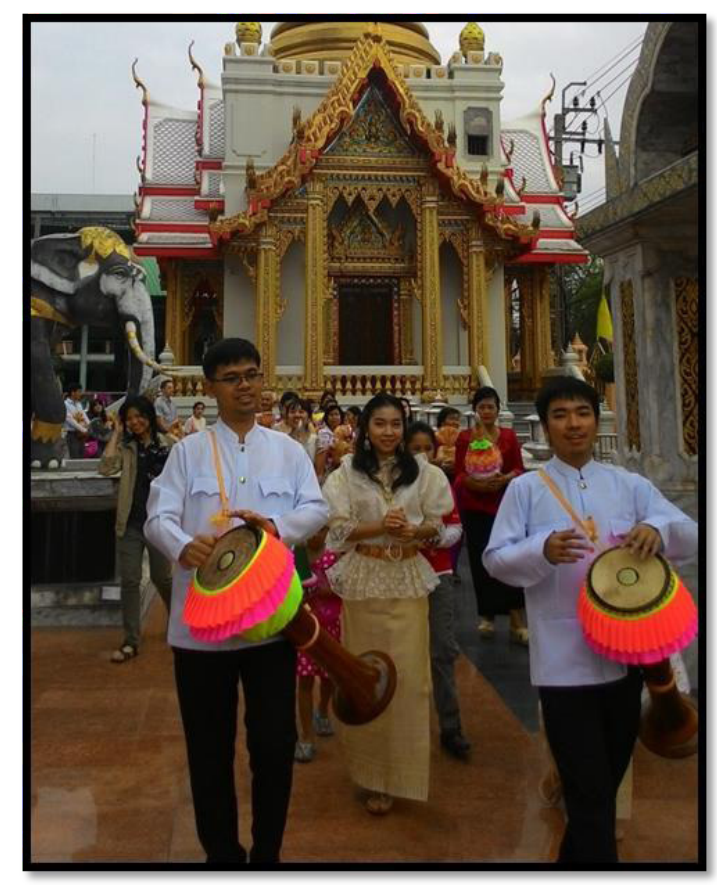

Figure 2. Klong Yao band playing as the head of the procession for ordination ceremony. (Photo: Chayuti Tassanawongwara, 2015)

\section{REFERENCES}

Ashcroft, Bill and Griffiths, Gareth and Tiffin, Helen. 2007. Post-colonial studies the key concepts $\left(2^{\text {nd }} E d\right)$. New York: Routhledge.

Bernard, Russell H. 1994. Research methods in anthropology: qualitative and quantitative approaches (second edition). Walnut Creek, CA: Alta Mira Press. 
Burke, Peter J. and Stets, Jan E. 2009. Identity theory. New York: Oxford University Press.

Denzin, N., \& Lincoln, Y. (Eds.). 2011. Handbook of qualitative research (4th ed). Thousand Oaks, CA: Sage.

Dueck B. 2007. Public and intimate sociability in First Nations and Metis fiddling.

(Ethnomusicology).

Eriksen, Thomas H., Ethnicity and Nationalism (London: Pluto Press, 1993).

Friedman, Jonathan, Cultural Identity \& Global Process (London: SAGE Publications Ltd, 1994).

Hogen, John P. Culture Identity, Pluralism and Globalization (Washington, D.C.: Cardinal Station, 2005).

Ibrahim, Zawawi, Representation, Identity and Multiculturalism in Sarawak (Kuala Lumpur: Vinlin Press, 2008).

Matusky, Patricia, Malaysian shadow play and music continuity of an oral tradition (Kuala Lumpur: Oxford University Press, 1993).

Merriam, S. Qualitative research: A guide to design and implementation. (San Francisco, CA: Jossey-Bass, 2009).

Montesano, Michael J. and Jory,Patrick, Thai South and Malay North (Singapore: NUS Press, 2008).

Pakawan Bundirek, The Manhora music of Malaysian Siamese in Kelantan, Malaysia (Bangkok: Kasetsart university, dissertation, 2010).

Parkinson, G., \& Drislane, R. Qualitative research. In Online dictionary of the social sciences. (Retrieved from http://bitbucket.icaap.org/dict.pl, 2011). Poole, Ross, Nation and Identity (London: Routledge, 1999).

Said, Edward W., Culture and Imperialism (New York: Knoft, 1993).

Stokes, Martin, Ethnicity, Identity and Music The musical construction of place (New York: Berg Publishers, 1997).

Tassanawadee Keawsanit, Status and role of ritual of the Siamese-Malaysian community in Malaysia (Bangkok: research, 2015).

Tawat Punnodok and Vimol Ketta, Thai sia din daen (Bangkok: Mac, 2009).

Turner, Victor W., The ritual process structure and anti-structure (London: Routledge, 1969).

Vajeeyaporn Chatavaraha, The Dikie Barat music of Thai people in Kelantan, Malaysia (Bangkok: Kasetsart university, dissertation, 2010).

Woodward, Kathryn, Identity and Difference (London: SAGE Publication Ltd, 1997).

Young, Robert J.C., Colonial desire hybridity in theory, culture and race (London: Routledge, 1995). 